
Table 1. Effect of Testicular Hyaldronidase on the Perme-
abILity of HUMan ARterial Tissde

\begin{tabular}{|c|c|c|c|c|c|}
\hline \multirow{3}{*}{ Sample } & \multirow{3}{*}{$\begin{array}{l}\text { Thick- } \\
\text { ness of } \\
\text { mem- } \\
\text { brane } \\
\text { (mm.) }\end{array}$} & \multicolumn{4}{|c|}{ Diffusion coefficient of glucose } \\
\hline & & \multicolumn{2}{|c|}{$\begin{array}{c}\text { Before } \\
\text { hyaluronidase }\end{array}$} & \multicolumn{2}{|c|}{$\begin{array}{c}\text { After } \\
\text { hyaluronidase }\end{array}$} \\
\hline & & $\begin{array}{l}\text { First } \\
\text { period }\end{array}$ & $\begin{array}{l}\text { Second } \\
\text { period }\end{array}$ & $\begin{array}{c}\text { First } \\
\text { period }\end{array}$ & $\begin{array}{l}\text { Second } \\
\text { period }\end{array}$ \\
\hline $\begin{array}{l}\text { (1) Thoracic } \\
\text { aorta } \\
\text { (2) Pulmonary }\end{array}$ & $0 \cdot 63$ & $0 \cdot 000082$ & $0 \cdot 000084$ & $0 \cdot 000103$ & 0.000134 \\
\hline $\begin{array}{l}\text { artery } \\
\text { (3) Pulmonary }\end{array}$ & $1 \cdot 15$ & $0 \cdot 000065$ & $0 \cdot 000070$ & $0 \cdot 000091$ & $0 \cdot 000089$ \\
\hline (4) Abdoryinal & 0.96 & $0 \cdot 000138$ & $0 \cdot 000111$ & $0 \cdot 000297$ & 0.000330 \\
\hline (5) Abdominal & $1 \cdot 33$ & $0 \cdot 000063$ & $0 \cdot 000050$ & $0 \cdot 000074$ & 0.000134 \\
\hline $\begin{array}{l}\text { aorta } \\
\text { (6) Pulmonary }\end{array}$ & 0.92 & 0.000078 & $0 \cdot 000086$ & 0.000086 & $0 \cdot 000079$ \\
\hline arter:y & $0 \cdot 89$ & $0 \cdot 000039$ & $0 \cdot 000033$ & $0 \cdot 000041$ & $0 \cdot 000044$ \\
\hline Mean & & $0 \cdot 000078$ & $0 \cdot 000072$ & 0.000115 & 0.000135 \\
\hline
\end{tabular}

before ex.ch set of diffusion periods to permit penetration of glucose through the membrane.

The glucose analyses were performed in duplicate by the colorimetric method of Nelson ${ }^{3}$, using the reagents described by Somogyi ${ }^{4}$. A Beckman $D U$ spectrophotometer was employed for the colorimetric determinations.

The results of the experiments are presented in Table 1. It will be seen that a definite increase in the permeability of the arterial tissue to glucose was observed in four of the six experiments, whereas in two experiments no significant change was noted.

The diffusion coefficients observed for glucose for human arterial tissue in the present work before treatment with hyaluronidase are of the same order of magnitude as the values reported by Kirk and Laursen $^{5}$ for aortic tissue. The higher average values found in the second period following treatment with hyaluronidase may be due to a continued action of hyaluronidase in the tissue membrane.

Division of Gerontology, JøRGEN MATZKE*

Washington University,

School of Medicine.

St. Louis, Missouri.

* St. Louis Heart Association Research Fellow. Present address Medical Department $A$, University Hospital, Copenhagen, Denmark.

${ }^{1}$ Kirk, J. E., and Dyrbye, M., J. Gerontol., 12, 23 (1957).

${ }^{2}$ Johnson, S. G., and Kirk, J. E., Anal. Chem., 27, 838 (1955).

${ }^{3}$ Nelson, N., J. Biol. Chem., 153, 375 (1944).

+ Somogyi, M., J. Biol. Chem., 195, 19 (1952)

${ }^{5}$ Kirk, J. E., and Laursen, T. J. S.. J. Gerontol., 10, 288 (1955).

\section{Electro-shock Seizure Threshold of Metacorticoid Hypertensive Rats}

IT has been shown ${ }^{1-5}$ that chronic administration of deoxycorticosterone acetate decreases brain excitability and potentiates anticonvulsant drugs, and that this effect is correlated with increased plasma and decreased brain intracellular sodium concentrations. In contrast, adrenal insufficiency produces the opposite effects ${ }^{2}$. Similarly, deoxycorticosterone acetate is known to be a relatively potent anasthetic steroid ${ }^{6}$.

Deoxycorticosterone acetate also produces, in the presence of dietary sodium, hypertensive cardio. vascular disease and disturbances in mineral appetite. After the cessation of chronic administration of deoxycorticosterone acetate to rats, a metacorticoid state ensues in which these alterations persist?.8. It is felt that this hypertensive disease is mediated at least in part by increased arteriolar intracellular sodium $^{8,9}$. It was of interest to determine whether the decreased brain excitability also persisted in metacorticoid rats.

Systolic blood pressures ${ }^{10}$ and electro-shock seizure thresholds ${ }^{11}$ were determined in 15 male SpragueDawley rats and in 30 similar rats that had previously received a subcutaneous implant of $20 \mathrm{mgm}$. deoxycorticosterone acetate and 1 per cent saline as drinking fluid for 3 months. ${ }^{8}$. Both groups were being maintained on tap water, however, when blood pressure and electro-shock seizure thresholds were determined. The electro-shock seizure threshold refers to the convulsive threshold to a 60 counts per sec. current, delivered by corneal electrodes for 0.2 sec., that does not vary more than $1 \mathrm{~m}$.amp. in 3 consecutive trials at least $48 \mathrm{hr}$. apart. The metacorticoid rats were found to have a mean electro-shock seizure threshold (35 m.amp.) that was not significantly different from that of the control rats $(33 \mathrm{~m}$.amp.), although their mean blood pressure ( $169 \mathrm{~mm}$. mercury) was significantly elevated from control levels $(129 \mathrm{~mm}$.).

If the mechanism of electro-shock seizure threshold elevation by deoxycorticosterone acetate involves decreased brain intracellular sodium, and the mechanism of blood-pressure elevation by deoxycorticosterone acetate involve increased arteriolar intracellular sodium, then perhaps the former is reversible while the latter is not.

F. M. STuRtevant*

Smith Kline and French Laboratories, Philadelphia, 1, Pa.

*Present address: Research Laboratories, Mead Johnsin and Company, Evansville 21, Indiana.

'Davenport, V., Amer. J. Physiol., 156, 322 (1949).

2 Woodbury, D., and Davenport, V., Amer. J. Physiol., 157. 237 (1949).

"Aird, R., and Gordon, G., J. Amer. Med, Assoc., 145, 715 (1951).

+ Woodbury, D., J. Pharmacol. Exp. Therap., 105, 29, 46 (1952)

${ }^{5}$ Timiras, P., Woodbury, D., and Goodman, L, J. Pharmacol. Exp. Therap., 112, 80 (1954).

'Selye, H., Proc. Soc. Exp. Biol. Med., 46, 116 (1941).

${ }^{7}$ Green, D., Saunders, F., Van Arman, C., Calvin, L., and Sturtevan:, F., Amer, J. Physiol., 170, 486 (1952).

${ }^{8}$ sturtevant, F., Ann. Int. Med., 49, 1281 (1958).

${ }^{9}$ Raab, W., J. Mt. Sinai Hosp., 19, 233 (1952).

to Kersten, H., Brosene, W., Ablondi, F., and Subbarow, Y., J. Lat). Clin. Med., 32, 1090 (i947).

11 Swinyard, E., .J. Amer. Pharmaceut. Assoc., sei. ed., 38, 201 1949),

\section{RADIOBIOLOGY}

\section{Delayed 'Primary' Effects in Chara vulgaris $\mathbf{L}$. subjected to $\mathbf{X}$-Rays}

'PRIMARY' or 'non-localized' effects in the form of clumping of metaphase chromosomes or the sticking together of sister chromatids in cells that complete mitosis shortly after irradiation during the period when mitotic frequency is decreasing have already been described by numerous investigators.

Study of the restoration process in the freshwates alga Chara vulgaris L. $(n=14)$ on X-radiation has shown that the effects referred to as primary could still occur long after irradiation, although re-establish. ment of the normal structure had already been achieved.

Irradiation was performed with unfiltered X-rays delivered by a Machlett A.E.G., 0 beryllium-window $\mathrm{X}$-ray tube operated at $40 \mathrm{kV}$. peak and $25 \mathrm{~m}$.amp. The dose-rate at the target distance employeri (12 cm.) was 14,000 r./min.. measured in air. The 